Розділ III. Історичні та порівняльні аспекти в теорії і практиці духовно-інтелектуального виховання й навчання

\title{
ДІЯЛЬНІСТЬ УКРАЇНСЬКОГО ВІЛЬНОГО УНІВЕРСИТЕТУ 1921-1945 РР.
}

\section{Єрмак Ю. I.}

кандидат педагогічних наук, доцент, завідувач кафедри педагогіки та педагогічної майстерності, Мелітопольський державний педагогічний

університет імені Богдана Хмельницького, м. Мелітополь, Україна

\section{Бунчук О. В.}

кандидат педагогічних наук, старший викладач кафедри педагогіки та педагогічної майстерності, Мелітопольський державний педагогічний університет імені Богдана Хмельницького, м. Мелітополь, Україна

У публікації розкрито діяльність Українського вільного університету як наукового осередку, утвореного украӥнською еміграцією в Свропі у міжвоєнний період. Увагу авторів зосереджено на роботі даного закладу як соціально-культурного інституту, у якому були створені умови українцями за кордоном для збереження національної ідентичності.

Ключові слова. Украӥнська еміграція; національна ідентичність; Украӥнський вільний університет, міжвоєнний період, інтелігениія.

The publication examines the activities of the Ukrainian Free University as a research center formed by Ukrainian emigration to Europe in the interwar period. The authors' attention is focused on the activities of this institution as a socio-cultural institution that allowed Ukrainians abroad to preserve their national identity.

Key words. Ukrainian emigration; national identity; Ukrainian Free University, interwar period, intelligentsia.

Розбудова України як незалежної та демократичної держави неможлива без всебічного та детального вивчення їі історії. Особливий інтерес викликає завершальний етап визвольних змагань та перехід українського війська разом із державними органами в еміграцію за кордон. Саме на сучасному етапі стоїть завдання проаналізувати діяльність українських емігрантів за кордоном, їхні прагнення підтримувати дух національної свідомості, дослідити їхній вплив на подальший розвиток ідеї боротьби за незалежність на теренах України.

Діяльність української політичної еміграції у країнах Європи в 20-х роках ХХ ст. на сучасному етапі перебуває у стані дослідження 
та вивчення. У радянській історіографії питання, що стосувалися періоду українського національного відродження в першій третині XX ст., систематично і цілеспрямовано спотворювалось та фальсифікувались. У контексті побудови незалежної України піднімаються питання встановлення історичної достовірності найвагоміших подій з життя країни в різні епохи. Для дослідження цього питання використовувались документи Центрального державного архіву вищих органів влади та управління України.

Діяльність навчальних закладів української еміграції міжвоєнного періоду не раз ставала об'єктом дослідження істориків, зокрема, С. Наріжного [2] та В. Ульяновських [10], О. Сухобокової [6], Т. Подоляки [3], В. Потульницького [4], О. Даниленка [1] та інших. Увага даної публікації зосереджуватиметься, головним чином, на розкритті заходів інститутів щодо збереження національної ідентичності українцями за кордоном.

Вже у першій половині 1920-х років українцями-емігрантами створюються чотири виші: Український вільний університет (УВУ), Українська господарська академія, Український високий педагогічний інститут імені М. Драгоманова та Українська студія пластичного мистецтва в Празі [5, с. 154].

Першим із вказаних вище закладів став Український вільний університет. Ініціаторами його створення виступили очолюваний Володимиром Кушніром віденський Союз українських журналістів і письменників, до складу якого входила академічна секція під головуванням професора Олександра Колесси. Ініціативу підтримали Товариство прихильників освіти, очолюване професором Станіславом Дністрянським, та Український соціологічний інститут, керівником якого був Михайло Грушевський [11]. За спогадами В. Кушніра, саме останній разом із Д. Антоновичем запропонував першу організаційну схему університету та був обраний ректором УВУ [9]. Проект М. Грушевського передбачав, що до читання лекцій могли запрошуватися викладачі, які не мали обов'язкової наукової кваліфікації; так само і від слухачів не вимагалося середньої освіти. Інших поглядів дотримувався О. Колесса, який вважав, що український університет має бути заснований за зразками західноєвропейських університетів із відповідними вимогами як до викладацького складу, так і до студентів [7]. На скликаній Союзом для вирішення цього 
питання нараді було підтримано О. Колессу. М. Грушевський самоусунувся від подальшої участі у створенні УВУ, а ректором було обрано О. Колессу [8].

Відкриття Українського вільного університету відбулося 17 січня 1921 р. у м. Відні, який недовгий час виступав центром української еміграції. 3 самого початку Український вільний університет мав висококваліфікований професорсько-викладацький склад. Це - Дмитро Дорошенко, Олександр Шульгін, Дмитро Антонович, Степан і Роман Смаль-Стоцькі, Володимир Старосольський, Сергій Шелухин, Кость Лоський, Агенор Артимович, Андрій Яковлєв та інші [5, с. 156].

Незважаючи на підтримку з боку чехословацького уряду, матеріальне становище Українського вільного університету, крім кількох перших років його існування у Празі, було дуже складним. Двічі — в 1925 i 1934 pp. — Університет стояв на порозі закриття. Однак він виявився єдиним з українських В3О в еміграції, якому вдалося вистояти і під час економічної кризи 1930-х років, і під час Другої світової війни. Празький період його історії завершило входження в Прагу радянських військ у травні 1945 р. Останній ректор А. Яковлів передав управління професору А. Волошину, який відстоював ідею залишити УВУ на території Чехословаччини. А. Яковлів з більшістю професорів покинули країну, а А. Волошин був заарештований органами НКВС. УВУ в Чехії був ліквідований, а майно частково знищено, частково розграбовано. 3 ініціативи історика й етнографа В. Щербаківського у 1946 р. діяльність університету було відновлено в Мюнхені, де заклад функціонує й до сьогодні [5, с. 156].

\section{Список використаних джерел:}

1. Даниленко О. Українські науково-освітні центри в Чехо-Словаччині як форма самоорганізації еміграції (1920-ті рр.). Вісник Київського національного університету імені Тараса Шевченка. Історія. № 1(114). Київ, 2013. C. 19-20.

2. Наріжний С. Українська еміграція. Прага, 1942. 372 с. 3.

3. Подоляка Т. А. Діяльність Зенона Кузелі в Українському Науковому Інституті в Берліні (1926-1945). Наука. Релігія. Суспільство. 2009. № 1. C. 34. URL:http://dspace.nbuv.gov.ua/bitstream/handle/123456789/29603/06Podolyaka. pdf?sequence $=1$ (дата звернення 18. 02. 2017).6 
4. Потульницький В. А. Український науковий інститут у Варшаві (19301939). Український археографічний щорічник. Нова серія. Вип. 3/4. Київ. 1999. C. 363-364. URL: http://nbuv.gov.ua/UJRN/Uashch_1999_3-4_25 (дата звернення 19. 02. 2017).7

5. Романова К. В. 3 історії українських навчальних закладів та наукових осередків Свропи у міжвоєнний період (за документами Центрального державого архіву зарубіжної україніки). Огляди джерел та докуметальні нариси. С. 153-167.

6. Сухобокова О. Український робітничий університет у Празі (1927-1931). URL: http://www.nbuv.gov.ua/old_jrn/Soc_Gum/Piufsp/2007_17/19.pdf(дата звернення 16. 02. 2017).5

7. Там само. Оп. 1. Спр. 130. Арк. 116.11

8. Там само. Оп. 2. Спр. 73. Арк. 35.12

9. Там само. 10

10. Ульяновська С., Ульяновський В. Українська наукова і культурницька еміграція у Чехо-Словаччині між двома світовими війнами. Українська культура. Лекції за редакцією Дмитра Антоновича. Пам'ятки історичної думки України. Київ. 1993. С. 477-498. URL: http://litopys.org.ua/cultur/ cult25.htm (дата звернення 16. 02. 2017). 4

11. ЦДАЗУ. Ф. 15. Оп. 2. Спр. 73. Арк. 35.9 